\title{
PELATIHAN KADER POSYANDU LANSIA DI WILAYAH KERJA PUSKESMAS KUMPAI BATU ATAS
}

\author{
Febri Nur Ngazizah ${ }^{1}$ Rukmini Syahleman ${ }^{2}$ Poppy Dwi Citra Jaluri ${ }^{3}$ \\ Jenny Oktarina ${ }^{4}$ \\ ${ }^{1234}$ STIKes Borneo Cendekia Medika Pangkalan Bun \\ ${ }^{3}$ Email : poppyjaluri@gmail.com
}

\begin{abstract}
ABSTRAK
Kader kesehatan adalah tenaga yang berasal dari masyarakat yang dipilih oleh masyarakat dan bekerja bersama untuk masyarakat secara sukarela (Mantra, 1983). Lanjut Usia (Lansia) merupakan seseorang yang mencapai usia 60 tahun keatas sesuai dengan Undang-Undang Nomor 13 Tahun 1998 tentang Kesejahteraan Lanjut Usia. Dari kegiatan penyuluhan ini dapat dilihat bahwa para kader dan masyarakat banyak yang belum memahami tentang pelayanan terhadap lansia. Diharapkan kader dan para lansia dapat memahami pola hidup sehat.
\end{abstract}

Kata kunci : Lansia

\section{TRAINING FOR ELDERLY POSYANDU KADER IN THE WORKING AREA OF THE BATU KUMPAI}

\begin{abstract}
Health cadres are energy derived from communities chosen by the community and working together for the community voluntarily (Mantra, 1983). Seniors are a person who reaches the age of 60 years and above in accordance with Act No. 13 of 1998 on elderly welfare. From this extension activities can be seen that cadres and many people who do not understand about the service to the elderly. It is hoped that cadres and seniors can understand healthy lifestyles.
\end{abstract}

Keywords: elderly

\section{PENDAHULUAN}

Lanjut usia (lansia) merupakan masa dimana orang akan mengalami pada akhirnya nanti. Banyak orang yang dapat menikmati masa tua akan tetapi sedikit pula yang mengalami sakit dan sampai meninggal tanpa dapat menikmati masa tua dengan bahagia. Setiap orang pasti ingin memiliki masa tua yang bahagia tetapi keinginan tidaklah selalu dapat menjadinyata. Di kehidupan nyata banyak sekali lansia-lansia yang menjadi depresi, stress dan menderita penyakit kronis. Kesegaran jasmani merupakan satu kesatuan yang tidak dapat dipisahkan dalam kegiatan olahraga. Kesegaran jasmani merupakan unsur utama manusia dalam menjunjung aktivitas sehari-hari. Manusia kadang lupa betapa 
pentingnya kesehatan apalagi diusia lansia. Sehat adalah kondisi optimal mental, fisik dan sosial seseorang, terbebas dari bibit penyakit sehingga mencapai produktivitas. Kesehatan masyarakat adalah ilmu dan seni untuk mencegah penyakit, memperpanjang hidup, mempromosikan kesehatan dan efisiensi dengan menggerakkan potensi masyarakat.

Secara global populasi lansia diprediksi terus mengalami peningkatan. Saat ini, populasi lansia di Indonesia termasuk dalam 5 besar negara dengan jumlah lansia terbanyak di dunia. Pada tahun 2014, jumlah lansia di Indonesia sekitar 18,781 juta jiwa dan diperkirakan pada tahun 2025 jumlahnya akan mencapai 36 juta jiwa (Depkes RI, 2015). Meningkatnya jumlah lansia juga perlu diimbangi dengan peningkatan kesehatan pada lansia termasuk pada penyakit hipertensi. Hipertensi merupakan kondisi dimana tekanan darah sistolik > $140 \mathrm{mmHg}$ dan tekanan diastolik > 90mmHg (World Health Organization, 2013).

Kader kesehatan masyarakat adalah laki-laki atau wanita yang dipilih oleh masyarakat dan dilatih untuk menanggani masalah-masalah kesehatan perseorangan maupun masyarakat setra untuk bekerja dalam hubungan yang amat dekat dengan tempat- tempat pemberian pelayanan kesehatan (WHO, 1995). Kader sebagai warga masyarakat setempat yang dipilih dan ditinjau oleh masyarakat dan dapat bekerja secara sukarela. Kader secara sukarela bersedia berperan melaksanakan dan mengelola kegiatan keluarga berencana di desa (Karwati, dkk, 2009).

\section{METODE PENELITIAN}

Metode yang kami gunakan dalam penyuluhan ini adalah dengan metode ceramah dan tanya jawab serta pmeriksaan kesehatan gratis.

\section{HASIL DAN PEMBAHASAN}

Kegiatan ini berupa penyuluhan mengenai optimalisasi peran kader dan pemeriksaan kesehatan diwilayah kerja Puskesmas Kumpai Batu Atas. Penyuluhan dilaksanakan di Puskesmas Kumpai Batu Atas. Tujuan kegiatan ini adalah untuk meningkatkan pengetahuan para kader dalam penyuluhan ini langsung disampaikan kepada para kader dan masyarakat oleh dosen Pengmas. Materi yang disampaikan mengenai penanganan kesehatan lansia.

Dari kegiatan ini diketahui bahwa para kader dan masyarakat ternyata masih banyak yang melalaikan kesehatan. Sehingga dirasa perlu dilakukan penyuluhan dan pemeriksaan kesehatan.

\section{KESIMPULAN DAN SARAN}

\section{Kesimpulan}

Setelah kegiatan program pengabdian kepada para kader dan masyarakat sekitar Puskesmas Kumpai Batu Atas ini terlaksana, para kader dan masyarakat menjadi mengerti dan paham tentang pentingnya kesehatan dan pemeriksaan dini.

\section{Saran}

Dengan adanya kegiatan penyuluhan pengabdian masyarakat ini seharusnya masyarakat dapat lebih dini mengenal tentang pentingnya kesehatan di usia lanjut. 


\section{DAFTAR PUSTAKA}

A Global Brief on Hypertension (2013): Silent Killer, Global Public Health Crisis. http://apps.who.int/iris/bitstrea m/10665/79059/1/WHO_DCO _WHD_2013.2_eng.pdf?ua $=1$ -Diakses Oktober 2017

Kemenkes RI (2016). Situasi DBD di Indonesia.

http://www.depkes.go.id/resou rces/download/pusdatin/infoda tin/infodatin dbd 2016.pdf

Depkes. Kepmenkes No.128/2004 tentang Kebijakan Dasar Pusat Kesehatan Masyarakat. Jakarta: Kementerian Kesehatan RI; 2004

WHO (2017). Dengue and Severe Dengue.

http://www.who.int/mediacent re/factsheets/fs117/en/ 